\title{
Bison use of fire-managed remnant prairies
}

\author{
MARIO E. BIONDINI, ALLEN A. STEUTER, AND ROBERT G. HAMILTON
}

Authors are professor, Department of Animal and Range Sciences, North Dakota State University, Fargo, N.D. 58105; director of science and stewardship, Nebraska, The Nature Conservancy, 431 North Maple Street, Ainsworth, Neb. 69210; and director of science and stewardship, Okla., The Nature Conservancy, P.O. Box 458, Pawhuska, Okla. 74056.

\begin{abstract}
This study was designed to: 1$)$ compare the landscape distribution patterns of bison on fire-managed prairie remnants in the tallgrass (Oklahoma), and mixed prairie (Nebraska); and 2) identify the extent to which fire and range site [topoedaphic classification of the landscape] affect bison distribution patterns.

This research was conducted at 2 sites: the Niobrara Valley Preserve (1990-1996), and the Tallgrass Prairie Preserve (1993-1996). At both preserves, bison selected burned areas during the growing season for 1-3 years and mostly avoided old burns and unburned areas. There was an interaction between fire and range site in selection patterns. In the absence of fire, bison mostly avoided both the Choppy Sand range sites at the Niobrara Valley Preserve and Loamy Prairie range sites at the Tallgrass Prairie Preserve. When they were burned, however, these sites were highly selected. The main difference in bison selection patterns between the Tallgrass Prairie Preserve and the Niobrara Valley Preserve was observed during the dormant season. In the Tallgrass Prairie Preserve, burned sites continue to be preferred during the dormant period for an average of 2 years while in the Niobrara Valley Preserve selections were random. These differences can be explained by 2 mechanisms: the fall and winter re-growth of forage at the more southern latitude and the significant physiognomic changes that fire can cause in tall grass prairies. Our study documents a continuing interaction between the ecological processes of the fire regime and bison distribution and abundance within 2 of the major prairie landscapes of the Great Plains, and provides critical details for understanding this relationship.
\end{abstract}

Key Words: Fire, grazing patterns, tallgrasss prairie, mixed prairie, range site.

Plains bison (Bison bison bison) were extirpated as a freeranging species in the last 2 decades of the nineteenth century. The factors that influenced pre-historic bison distribution (Hanson 1984, McHugh 1972), and the distribution of their impacts on the biotic and abiotic environment (England and

Research was funded by grants from The Nature Conservancy Ecosystem Research Program, USDA NRICGP 93-0051, and the National Science Foundation DEB-9627928.

Manuscript accepted 20 Oct. 1998.

\section{Resumen}

El objetivo de este estudio fue: 1) comparar el pastoreo de bisontes en pastizales nativos de Oklahoma y Nebraska manejados con fuego; y 2) determinar si el fuego influencia el uso de diversos "range sites" (range site es una combinacion nespecifica de topografia y suelos).

El experimento se condujo en dos lugares: la Niobrara Valley Preserve (1990-1996), y la Tall Grass Prairie Preserve (1993-1996). En ambos lugares, durante la epoca the crecimiento, los bisontes pastorearon de 1 a 3 años seguidos secciones recientemente quemadas y evitaron secciones no quemadas o quemadas mas the 3 años atras. La intensidad de uso fue influenciada por una interaccion entre el fuego y los range sites. Los bisontes pastorearon livianamente los Choppy Sand range sites en la Niobrara Valley Preserve y los Loamy Prairie range sites en la Tallgrass Prairie Preserve. Los mismos range sites, sin embargo, fueron intensamente pastoreados despues de la quema. Durante el otoño y el invierno los bisontes en la Tallgrass Prairie Preserve pastoreando intensament por 2 años seguidos las secciones quemadas, mientras que en la Niobrara Valley Preserve no se observaron diferencias en el uso de secciones quemadas y no quemadas. Esta disparidad se debio a: (a) la continuacion del crecimiento de los pastos en el otoño y parte del invierno en la Tallgrass Prairie Preserve; y (b) la alteracion que el fuego causo a la fisionomia de las praderas de la Tallgrass Prairie Preserve. Demostramos una interaccion entre el pastoreo de los bisontes y los procesos ecologicos generados por distintos regimenes de fuego y proveemos detalles tecnicos para el uso de fuego en estas praderas.

DeVos 1969, Malin 1953), thus, are generally unknown. Following the near extinction of bison, the Great Plains were developed for intensive agriculture, transportation corridors, and cities. Bison herds are once again expanding, although this time on prairie fragments within the developed landscape. These remnant prairies are critical to conserving biological diversity within the Great Plains (Samson and Knopf 1996). The interruption of landscape-scale processes, however, continues to be an overlooked mechanism reducing biodiversity (Leach and Givnish 1996). In commercial livestock operations neither large grazers nor fire are managed, for the most part, to preserve or restore ecological processes. Instead, they are managed to achieve individual species, or management unit objectives. 
Abiotic factors such as weather, topography, soils, and distance from water are suggested as the primary determinants of the large-scale distribution patterns of large herbivores (see review by Bailey et al. 1996). At smaller scales, the animal's spatial memory regarding factors such as forage composition, quantity and quality serve to improve foraging efficiency and define grazing patterns (Bailey et al. 1996). Biotic factors, therefore, should play a more significant role in defining bison distribution than abiotic ones within fragmented prairie remnants than on an unbounded prairie landscape. The modifications of many ecosystems processes (net primary production, nutrient cycling, etc.) by large grazers are widely recognized (Hobbs 1996). At moderate stocking rates, large grazers do not appear to influence, in the long term, plant species assemblages within plant communities, or alter the trajectory of plant succession at the landscape level (Jefferies et al. 1994, Biondini et al. 1998). Large grazers, however, have considerable short-term effects on vegetation at small scales. Examples include changes in bunchgrass size and tiller dynamics (Briske and Anderson 1990, Pfeiffer and Hartnett 1995), plant species diversity (Collins 1987, Hartnett et al. 1997), and plant above-ground biomass and live:dead ratio (Coppock et al. 1983, McNaughton 1984).

Great Plains land conversions and management have probably caused larger changes in landscape-scale processes than the replacement of bison grazing with cattle (Bos taurus) grazing (Hartnett et al. 1997). Yet, significant differences exist between the physiology, morphology, social behavior, and foraging ecology of bison and cattle which may make bison more adapted to some Great Plains grasslands (Christopherson et al. 1978, Peters and Slen 1964, Plumb and Dodd 1993, Towne et al. 1988). Bison select for the dominant perennial grasses forming the prairie matrix, show a strong preference for areas with young regrowth following fire and grazing, avoid wooded or broken topography during the breeding season, and spend relatively little time around water sources (Coppock and Detling 1986, Plumb and Dodd 1993, Shaw and Carter 1990, Steuter et al. 1995, Vinton and Hartnett 1992, Vinton et al. 1993, Coppedge et al. 1998).
Prairie preserves and native grassland pastures are relatively small considering the mobility of bison. Most of the abiotic factors associated with these prairie fragments (e.g. climate, weather, topography, soils) remained scaled similar to their original condition. The fire regime, however, can be re-scaled through the use of prescribed burning. Localized versions of the regional fire regime driven by a real-time fuel-forage interaction (Steuter et al. 1990) are implemented on several Great Plains preserves managed by The Nature Conservancy. Bison have been introduced as year-long, unsupplemented residents of these prairies.

The native rangelands of the mixedgrass and tallgrass prairie have been highly fragmented by farmland. Although the ecology of cattle grazing on prairie fragments has been studied intensively for 75 years [e.g Weaver and Clements 1938, Dyksterhuis 1949], there have been no opportunities, until recently, to study the ecology of bison grazing on relatively large mixed and tallgrass prairies managed with fire. During the last 20 years private bison ranches have developed throughout the central and eastern Great Plains. Many of these operations are based on native prairie remnants of high conservation value due to their rarity. Since bison offer previously unavailable management alternatives for these native prairie remnants, we have initiated studies to explore the contemporary response of these rangelands within the context of the evolutionary fire regime.

The objectives of this study were: 1) to compare the landscape distribution patterns of bison on fire-managed prairie remnants in the Tallgrass (Oklahoma), and Mixed prairie (Nebraska); and 2) to identify the extent to which fire and range site [topo-edaphic units of the landscape] affect bison distribution patterns. Results from this study should provide part of the framework for placing the aboriginal landscape-scale process of bison grazing within the context of contemporary prairie remnants.

\section{Materials and Methods}

\section{Site Description}

The research was conducted at 2 sites: the Niobrara Valley Preserve
(1990-1996), and the Tallgrass Prairie Preserve (1993-1996). Both preserves are owned and managed by The Nature Conservancy. The Niobrara Valley Preserve is located in Brown, Cherry, and Keya Paha counties, Nebr. on the northern edge of the Sandhills $\left(42^{\circ} 46^{\prime} \mathrm{N}, 100^{\circ}\right.$ $\left.00^{\prime} \mathrm{W}\right)$. The Sandhills are an extensive area of stabilized dunes dominated by bluestem (Schizachyrium scoparium Michx., Andropogon gerardii Vitman) and prairie sandreed (Calamovilfa longifolia Hook.) (Shiflet 1994). The Niobrara river and valley are significant features of the study site. The climate is continental with an average precipitation of $559 \mathrm{~mm}$ year $^{-1}$, and mean daily temperatures that range from $-5.7^{\circ} \mathrm{C}$ in January to $24^{\circ} \mathrm{C}$ in July. The experiment was conducted in a 3,000 ha pasture established in 1988, with a bison stocking rate of 1.0 AUM $\mathrm{ha}^{-1}$ year $^{-1}$. An AUM is the amount of forage that a $454 \mathrm{~kg}$ bison consumes in 1 month (360 kg dry-wt., Heitschmidt and Taylor 1991). The bison pasture has 4 dominant range sites (Voightlander et al. 1992) (Table 1).

The Tallgrass Prairie Preserve is located in the northern half of the Osage Hills, Okla. $\left(36^{\circ} 50^{\prime} \mathrm{N}, 96^{\circ} 25^{\prime} \mathrm{W}\right)$. The Osage Hills, an extension of the Flint Hills, are characterized by shallow to deep soils over limestone and limy shale (often exposed) and a well established drainage system. The study site is dominated by a bluestem prairie (Shiflet 1994) with savanna type vegetation occurring in the stream courses and in exposed bedrock areas. The climate is continental with an average precipitation of $877 \mathrm{~mm}$ year $^{-1}$, and average monthly temperatures that range from a low of $-3.3^{\circ} \mathrm{C}$ in January to a high of $33.3^{\circ} \mathrm{C}$ in July . The study site was established in 1993 in a 1,970 ha pasture which was subsequently expanded to 2,575 ha in the Fall of 1995, and 2,875 ha in the Spring of 1996 . The bison stocking rate, however, was kept constant at 1.2 $\mathrm{AUM}$ ha $^{-1}$ year $^{-1}$. The bison pasture has 6 dominant range sites (Bourlier et al. 1979) (Table 2).

\section{Fire Management}

The study sites are managed with prescribed burning designed to mimic the seasonal distribution and return interval of fires for the pre-European settlement period (Steuter et al. 1990). Approximately $13 \%$ of the Niobrara Valley Preserve and $20 \%$ of the Tallgrass 
Table 1. Niobrara Valley Preserve range site description, dominant vegetation, and estimated production.

\begin{tabular}{|c|c|c|c|c|}
\hline Range Site & Area & Description & Dominant Vegetation & Estimated Production \\
\hline Sand & $\begin{array}{l}(\%) \\
35\end{array}$ & $\begin{array}{l}\text { Deep, well drained, coarse } \\
\text { textured soils on level to } \\
\text { gently rolling uplands }\end{array}$ & $\begin{array}{l}\text { Andropogon hallii, Panicum virgatum, } \\
\text { Schizachyrium scoparium, Calamovilfa } \\
\text { longifolia, Eragrostis trichodes, and } \\
\text { Bouteloua hirsuta. }\end{array}$ & $\begin{array}{l}\left(\mathrm{kg} \mathrm{ha}^{-1}\right) \\
2600\end{array}$ \\
\hline Choppy Sands & 40 & $\begin{array}{l}\text { Deep well drained coarse } \\
\text { textured soils on hilly } \\
\text { uplands with stablized } \\
\text { dunes }\end{array}$ & $\begin{array}{l}\text { Andropogon hallii, Panicum virgatum, } \\
\text { Calamovilfa longifolia, Schizachyrium } \\
\text { scoparium, Stipa comata, Eragrostis trichodes, } \\
\text { Bouteloua hirsuta, and Muhlengbergia } \\
\text { pungens. }\end{array}$ & , \\
\hline $\begin{array}{l}\text { Shallow to } \\
\text { Gravel }\end{array}$ & 20 & $\begin{array}{l}\text { Moderately fine to coarse } \\
\text { textured soils underlain with } \\
\text { gravel and coarse sand at } \\
\text { depths } 20 \mathrm{~cm} \text { to } 50 \mathrm{~cm}\end{array}$ & $\begin{array}{l}\text { Bouteloua gracilis, Bouteloua hirsuta, } \\
\text { Calamovilfa longifolia, Stipa comata, } \\
\text { Andropogon hallii, and Schizachyrium } \\
\text { scoparium }\end{array}$ & 1600 \\
\hline Sandy Savanna & 5 & $\begin{array}{l}\text { Level to very steep areas on } \\
\text { breaks or riparian areas } \\
\text { characterized by grasslands } \\
\text { interspersed by mature trees } \\
\text { and brush }\end{array}$ & $\begin{array}{l}\text { Grasslands interspersed with mature trees } \\
\text { and brushes }\end{array}$ & Variable \\
\hline
\end{tabular}

Prairie Preserve pastures are burned each year to simulate the average firereturn interval of 7.5 and 5 years, respectively, estimated for the study sites in question (Wright and Bailey 1982). On both study sites, approximately $80 \%$ of the burns occur during the dormant season with the remainder taking place during the growing season to reflect seasonal differences in ignition sources, fuel conditions, fire intensity, and rates of fire spread (Higgins 1986, Cheney et al. 1993). Areas to be burned are selected from landscape units that meet a minimum size ( $>15 \mathrm{ha}$ ) using a weighted random procedure. The weighting factor is fine fuel accumulation immediately prior to burn date (the higher the fuel accumulation the higher the probability of selection). A mini- mum threshold for fine fuel capable of carrying a fire is set at $1,000 \mathrm{~kg} \mathrm{ha}^{-1}$ as estimated from Forest Service models using local data (Burger and Rothermel 1984, Andrews 1986).

\section{Bison Location}

We recorded the landscape distribution of "mixed" bison groups which consist of adult females, juvenile

Table 2.. Tall Grass Prairie Preserve range site description, dominant vegetation, and estimated production.

\begin{tabular}{|c|c|c|c|c|}
\hline Range Site & Area & Description & Dominant Vegetation & Estimated Production \\
\hline & $(\%)$ & & & $\left(\mathrm{kg} \mathrm{ha}^{-1}\right)$ \\
\hline Claypan & 6 & $\begin{array}{l}\text { Level to gently sloping soils, fine to } \\
\text { medium-textured topsoils, impervious } \\
\text { subsoils within } 50 \mathrm{~cm} \text { of the surface. }\end{array}$ & $\begin{array}{l}\text { Schizachyrium scoparium, Andropogon } \\
\text { gerardii, and Panicum virgatum }\end{array}$ & 3000 \\
\hline Loamy Bottomland & 5 & $\begin{array}{l}\text { Alluvial soils that are subject to } \\
\text { flooding (riparian zones and overflow } \\
\text { areas) }\end{array}$ & $\begin{array}{l}\text { Panicum virgatum, Sorghastrum nutans, } \\
\text { and Andropogon gerardii with mature } \\
\text { trees and shrubs compromise } 20 \% \text { of the } \\
\text { vegetation). }\end{array}$ & 6100 \\
\hline Loamy Prairie & 65 & $\begin{array}{l}\text { Upland soils more than } 50 \mathrm{~cm} \text { deep, } \\
\text { with a loamy texture and permeable } \\
\text { subsoils. }\end{array}$ & $\begin{array}{l}\text { Andropogon gerardii, Panicum virgatum, } \\
\text { Sorghastrum nutans, and Schizachyrium } \\
\text { scoparium }\end{array}$ & 5200 \\
\hline Shallow Savanna & 5 & $\begin{array}{l}\text { Loamy upland soils that are less than } \\
50 \mathrm{~cm} \text { deep with exposed ledge rock and } \\
\text { very shallow soils intermixed with } \\
\text { deeper soils. }\end{array}$ & $\begin{array}{l}\text { Mature trees and shrubs compromise } 20 \% \\
\text { of the vegetation with Schizachyrium } \\
\text { scoparium and gerardii as the dominant } \\
\text { herbaceous species. }\end{array}$ & 2100 \\
\hline Shallow prairie & 16 & $\begin{array}{l}\text { Rocky and rough upland soils, less than } \\
50 \mathrm{~cm} \text { deep, slopes of less than } 20 \%\end{array}$ & $\begin{array}{l}\text { Schizachyrium scoparium, Bouteloua } \\
\text { curtipendula, Andropogon gerardii, } \\
\text { Sorghastrum nutans, and Panicum } \\
\text { virgatum. }\end{array}$ & 2300 \\
\hline Sandy Savanna & 3 & $\begin{array}{l}\text { Loamy or sandy texture upland soils } \\
\text { more than } 50 \mathrm{~cm} \text { depth with gently to } \\
\text { steep slopes. }\end{array}$ & $\begin{array}{l}\text { Schizachyrium scoparium, Andropogon } \\
\text { gerardii, and Sorghastrum nutans. }\end{array}$ & 3300 \\
\hline
\end{tabular}


females and males, and bulls generally younger than 4 years old. During the rut, older bulls were also part of these mixed groups. The location of bison groups within the pasture was determined throughout the year by regular (once or more per week) visual census conducted during the morning and afternoon. Determining the location of at least $90 \%$ of the bison herd was considered a minimum for a complete sample. Animal location was recorded with the use of USGS 7.5' topography series maps of the pasture overlain with a permanent 16 ha grid system. Total number of bison observed within each grid was aggregated on a 12 month basis to reflect growing season (April to October) or non growing season (November to March) distribution patterns.

The bison grid data, as well as the geographic location of prescribed burns and range sites were mapped onto 1:24000 USGS Quads and transferred to a Geographic Information System (GIS) using Erdas 8.1 (Erdas, Inc.). GIS layers corresponding to bison, fire, and range site locations were used to determine bison distribution patterns as a function of fire and range sites.

\section{Statistical Analysis}

The null hypothesis that bison select burned areas or range sites randomly and in proportion to their area was tested with the use of Chi square analysis (Manly 1993):

$$
\chi_{(\alpha ; N R-1 d f)}^{2}=\sum_{i=1}^{i=N R} \frac{\left(\mathbf{u}_{\mathrm{i}}-\mathbf{u}_{+} \pi_{\mathrm{i}}\right)^{2}}{\mathbf{u}_{+} \pi_{\mathrm{i}}}
$$

where $\mathrm{NR}=$ number of categories (burned sites by year, or range sites); $\mathrm{u}_{\mathrm{i}}=$ the number of animals using resource $i ; u_{+}=$total number of animals; $\pi_{\mathrm{i}}=$ proportion of resource $\mathrm{i}$ (proportion of burned or range site area $i$ in the pasture). Interactions between burned area and range site selection were tested in a similar fashion with Chi square contingency tables (Mosteller and Rourke 1973). If either test was significant (null hypothesis rejected) we proceeded with the following analysis.

The $100(1-\alpha) \%$ multiple confidence interval for selection ratios was calculated as follows (Manly 1993):

$C I\left(w_{i}\right)= \pm z_{\alpha /(2 N R)} \sqrt{\frac{\left(1-\pi_{i}\right)}{u_{+} \pi_{i}}}$ where $w_{i}=\frac{u_{i}}{u_{+} \pi_{i}}$ where $z_{\alpha /(2 N R)}$ is the Bonferroni adjusted $\mathrm{z}$ value for the standard normal distribution; $\mathrm{w}_{\mathrm{i}}=$ ratio between the proportion of bison using resource $i$ and the one expected under the null hypothesis. Deviations of selection ratios from the null hypothesis $\left(\mathrm{w}_{\mathrm{i}} \neq 1\right.$ with $\left.\mathrm{P}<\alpha\right)$ were tested using a $1 \mathrm{df}$. Chi square analysis of the following form (Manly 1993):

$$
\chi_{(\alpha / 2 \mathrm{NR}-1)) ; 1 d f)=}^{\left(\mathbf{1}-\pi_{\mathrm{i}}\right)}
$$

To test whether the selection of a given resource affects the use of other resources equation 3 was modified as follows:

$$
\chi_{(\alpha / 2 \mathrm{NR}-1)) ; 1 d f)}^{2}=\frac{\left(\mathbf{w}_{\mathrm{i} / \mathrm{j}=\mathrm{J}^{-1}}\right)^{2}\left(\mathbf{u}_{+}-\mathrm{J}\right) \pi_{\mathrm{i} / \mathrm{j}=\mathrm{J}}}{\left(\mathbf{1}-\pi_{\mathrm{i} / \mathrm{j}=\mathrm{J}}\right)}
$$

where

$$
\mathbf{w}_{\mathrm{i} / \mathrm{j}=\mathrm{J}}=\frac{u_{\mathrm{i}}}{\left(\mathrm{u}_{+}-\mathrm{J}\right) \pi_{\mathrm{i} / \mathrm{j}=\mathrm{J}}} ; \pi_{\mathrm{i} / \mathrm{j}=\mathrm{J}} \frac{\pi_{\mathrm{i}}}{\sum_{\substack{l=\mathrm{NR} \\ l=1, l \neq j}}^{\pi_{1}}}
$$

where: (a) $\pi_{\mathrm{i} / \mathrm{j}=\mathrm{J}}$ is the conditional probability of selecting any of the remaining NR-1 available resource $(i=1, . ., \mathrm{NR}-1$; $\mathrm{i} \neq \mathrm{j}$ ) once resource $\mathrm{j}$ has been selected; and (b) $w_{i / j=J}$ is the ratio between the number of bison selecting resource $i$ $(\mathrm{i}=1, ., \mathrm{NR}-1 ; \mathrm{i} \neq \mathrm{j})$ and the one expected

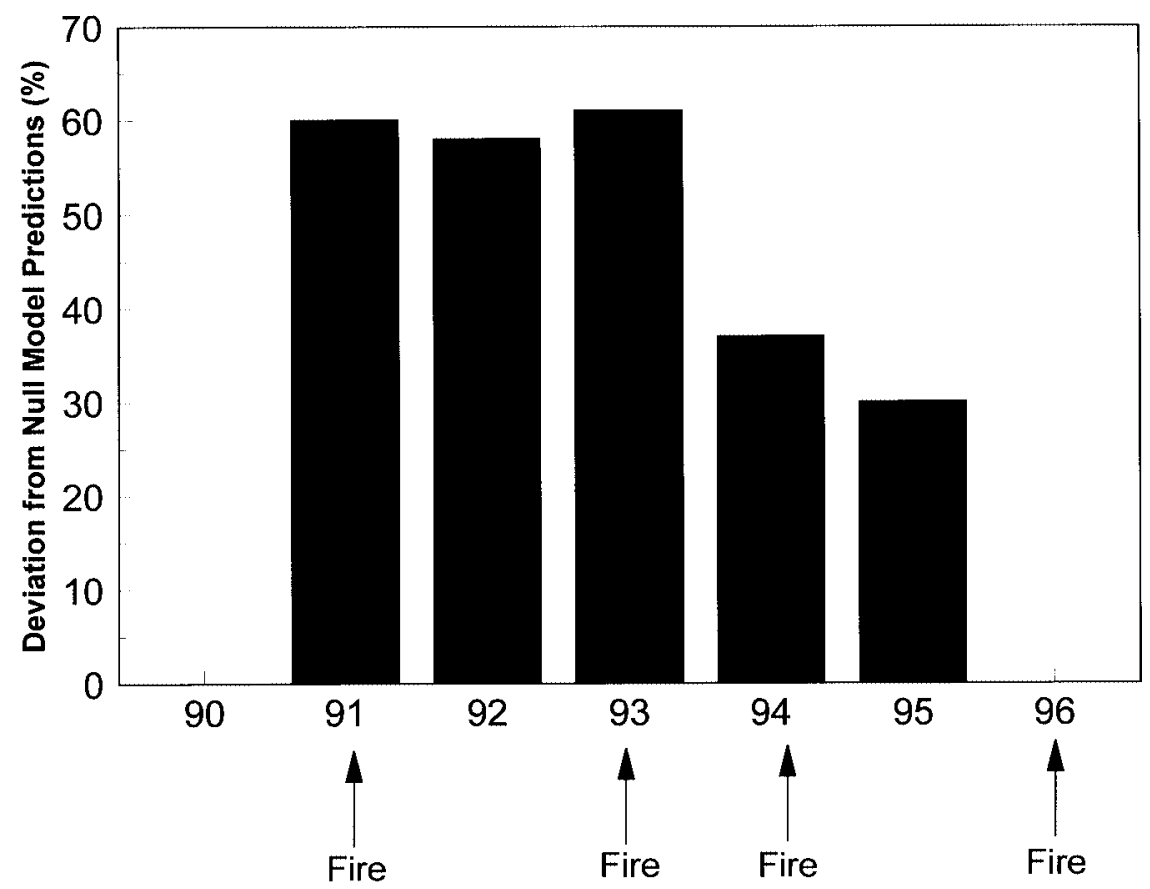

Fig. 1. Niobrara Valley Preserve. Aggregate bison selection of burned areas (sum of all burned areas) during the growing season. The bars represent significant departure $(P<0.01)$ from null model predictions (bison use burned areas randomly and in proportion to their area) under a null hypothesis that incorporates the knowledge that $\mathbf{J}$ number of bison have already selected resource $\mathrm{j}$ (expected number of $u_{+}{ }^{-} \mathrm{J}$ bison selecting each of the remaining NR-1 resources). This analysis was used to determine: (a) whether the use by bison of current burns affects the selection of previous burns; and (b) whether fire restricts selection of range site and vice versa.

All reported differences are statistically significant at the $1 \%$ level unless otherwise stated.

\section{Results}

\section{Niobrara Valley Preserve Growing Season}

Before prescribed burning treatments were applied (1990) selection of the landscape units that were eventually burned followed null model predictions $\left(\left[\mathrm{w}_{\mathrm{i}}-1\right]=0\right)$ (Fig. 1). When treatments began, aggregate selection of burned areas (sum of all burned areas) by bison was higher than null model predictions from 1991 to 1995 , but it declined from an average of $60 \%$ above model predictions for the 1991-1993 period to $30 \%$ in 1995 (Fig.1). By 1996, however, the 

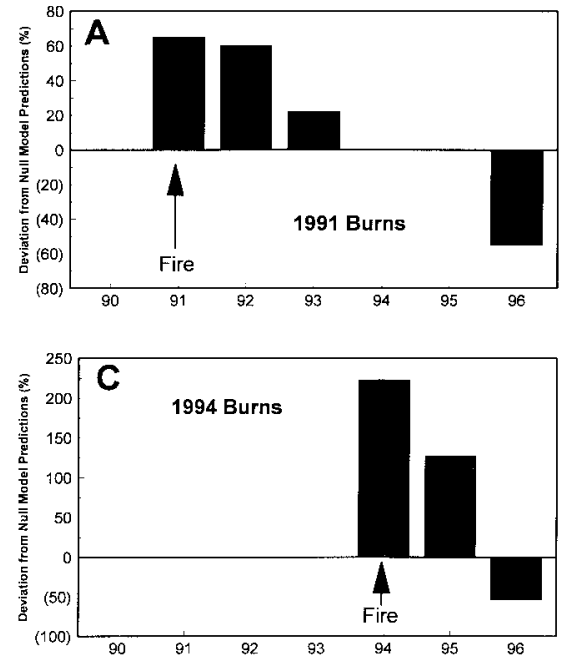

Fig. 2. Niobrara Valley Preserve. Bison selection of individual burn units during the growing season. The bars represent significant departure $(P<0.01)$ from null model predictions (bison use burned areas randomly and in proportion to their area). (A) 1991 burns; (B) 1993 burns; (C) 1994 burns; (D) 1991 and 1996 burned areas that overlap.

aggregate selection of burned areas returned to null model predictions. The 1996 changes in selection patterns occurred because, for the first time, bison began to select new burns and avoid old ones (Fig. 2).

The 1991 burns were selected by bison for 3 consecutive years (Fig. 2), but avoided in 1996. The area burned in 1993 had been avoided by bison in 1992 but was highly selected when burned in 1993 (Fig. 2). Unlike the 1991 burn, however, the 1993 fire effect only lasted for 1 year primarily because of a switch in selection to the 1994 burn (Fig. 2). Selection of areas burned in 1994 had followed null model predictions from 1991 to 1993 , but were substantially selected in 1994 and 1995. As with the 1991 burn, however, bison avoided this area in 1996. The fire of 1996 overlapped by $60 \%$ with the area burned in 1991 and was substantially (> $200 \%$ above null model predictions) selected by bison.

The Choppy Sands range site was mostly avoided by bison by (an average of $35 \%$ below null model predictions) from 1990 to 1993 but was highly selected in 1996 (Fig. 3). Sand range sites were selected above null model predictions only twice during the 7 years of the study.

The 1996 selection of the Choppy Sands reflects the capacity of fire to override range site effects since $93 \%$ of the 1996 burns occurred over this range site (Fig. 4). Fig. 4 shows the bison selection ratios of Choppy Sands contin-
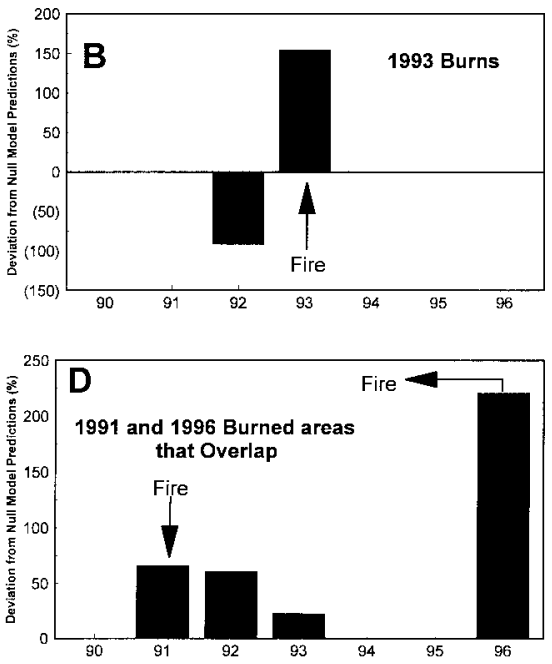

1996 results are a clear example of fire dominating range site effects. As shown in Fig. 3, bison in 1996 substantially selected Choppy Sands, but when the fire effect is taken out of their selection patterns, there is no selection for Choppy Sands (Fig. 4).

\section{Non-Growing Season}

Bison selection patterns during the non-growing season were markedly different from the ones observed during the growing season. There was no significant effect of fire upon selection patterns for the entire 7 year period. Choppy Sands were avoided only 2 out of the 7 years, while Sands were selected above null model predictions only once during the same period of time (Fig. 3).

\section{Tallgrass Prairie Preserve Growing Season}

Contrary to the selection patterns observed at the Niobrara Valley Preserve, there was not an aggregate selection of burned areas (sum of all burned areas) early in the study period. This result is probably due to the fact that while forage production in the Tallgrass Prairie Preserve was twice that of the Niobrara Valley Preserve, the
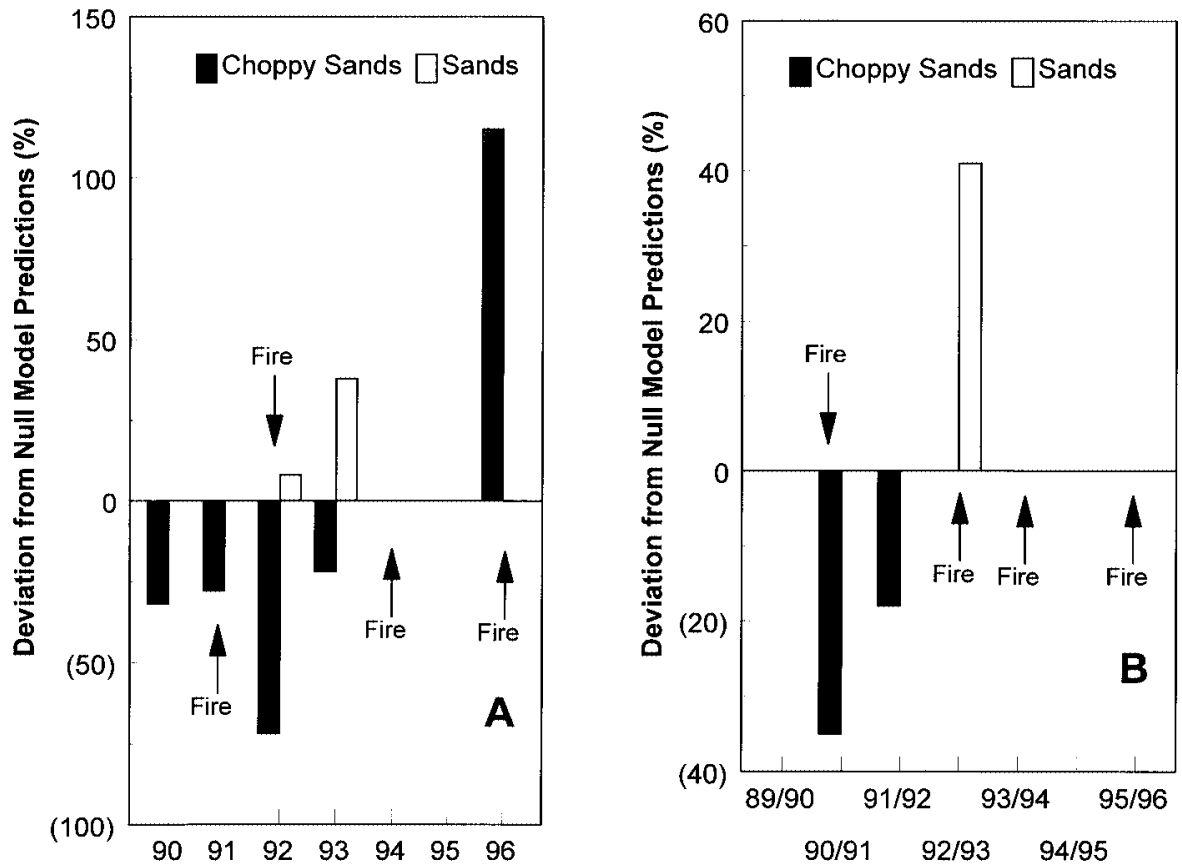

Fig. 3. Niobrara Valley Preserve. Bison selection of Sands and Choppy Sand range sites for both the growing and non-growing season. The bars represent significant departure $(\mathrm{P}<\mathbf{0 . 0 1})$ from null model predictions (bison use range sites randomly and in proportion to their area). (A) Growing season; (b) Non-growing season. 


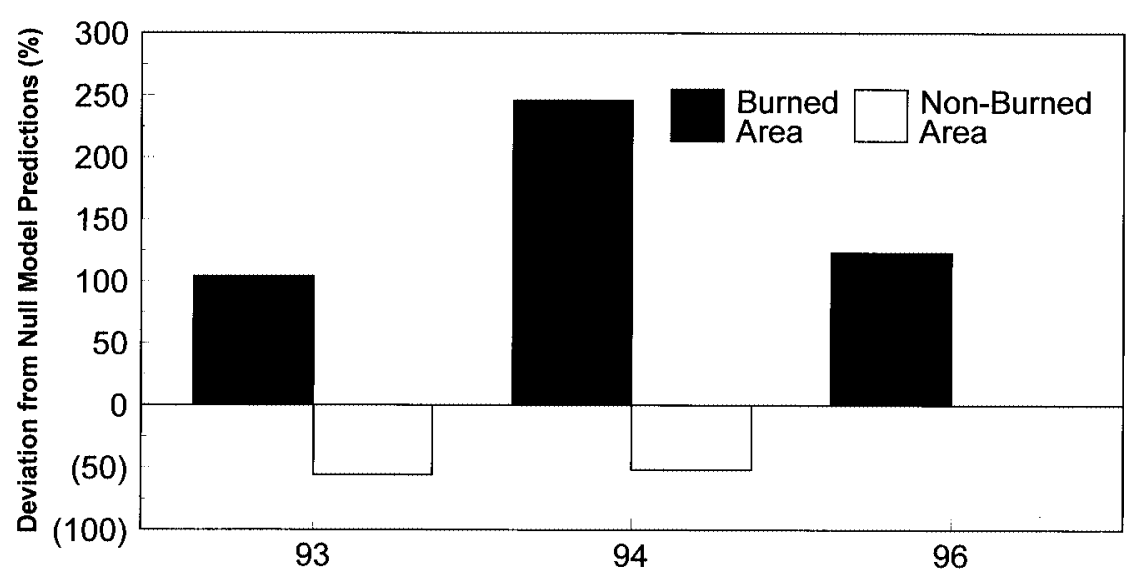

Fig. 4. Niobrara Valley Preserve. Bison selection of Choppy Sands range sites as affected by fire. The bars represent significant departure $(P<0.01)$ from the conditional null model predictions as estimated by equation 4 .

bison stocking rate was only $20 \%$ higher. Selection of burned areas at the Tallgrass Prairie Preserve was high (> $200 \%$ ), but it was restricted to the most recent burns (Fig. 5a-c). As in the case of year 6 at the Niobrara Valley Preserve there was a significant avoidance of old burns as well as non-burned areas (Fig. $5 \mathrm{a}-\mathrm{c})$.

The only interaction between range sites and fire was observed on the

Loamy Prairie range site (Fig. 5d). Use of Loamy Prairie followed the pattern of the overall landscape, which is not unexpected since this site represents $65 \%$ of the pasture. Use of this range site as a whole follows null model predictions $(\mathrm{w}=1)$ in all growing seasons. But, the results again showed the ability of fire to override range site effects: the burned area was highly selected $(>150 \%)$ in 1994 and 1995 while the unburned areas
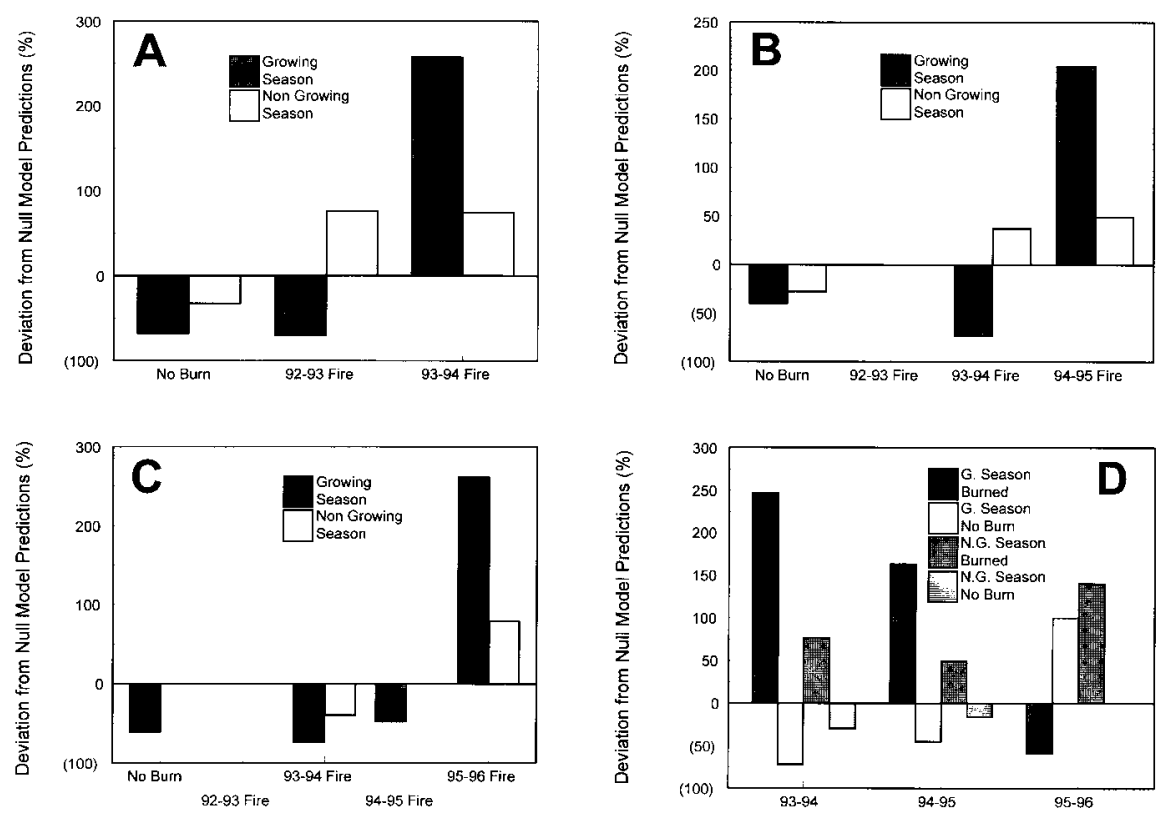

Fig. 5. Tall Grass Prairie. Selection of individual burn units and the Loamy Prairie range site for both the growing and non-growing season. The bars for the individual burn units represent significant departure $(\mathbf{P}<\mathbf{0 . 0 1})$ from null model predictions (bison select burned areas randomly and in proportion to their area). For the Loamy prairie site the bars represent significant departure $(P<0.01)$ from the conditional null model predictions as estimated by equation 4. (A) 1993-1994 Bison selection patterns by fire; (B) 1994-1995 Bison selection patterns by fire; (C) 1995-1996 Bison selection patterns by fire; (D) Bison selection of Loamy Prairie Range site as constrained by fire. were mostly avoided (40\% reduction from null model predictions) (Fig. 5d).

\section{Non Growing Season}

Non-growing season response to fire was similar to that observed in the growing season, but lasted for 2 years rather than 1 and departures from null model predictions were on average $60 \%$ lower (Fig. 5a-d). These patterns were substantially different from those observed at the Niobrara Valley Preserve where there was no response to fire during the non growing season. A similar pattern was observed vis a vis range site. Again the only significant interaction was observed on the Loamy Prairie where the burned areas were highly selected, while the unburned ones were either avoided $(\approx 25 \%$ below null model predictions), or followed null model predictions (Fig. 5d). As in the case of fire, the response was on average $60 \%$ lower than in the growing season.

\section{Discussion}

The strong attraction of bison to newly burned areas has been documented by others in western and more wooded mixed prairie areas (Coppock and Detling 1986, Shaw and Carter 1990). These studies described bison response to unique fire events largely as a response to a patch of high quality forage. Steuter et al. (1990) theorized that in the mixed prairie, bison selection of burned areas should last for 2 to 3 years and should be limited to the growing season. The hypothesis was based on the known effects of fire on annual forage production and seasonal forage quality.

Various studies have demonstrated the link between forage quality and fire (Britton and Steuter 1983, Ohr and Bragg 1985, Coppock and Detling 1986). The increase in forage quality after fire can be prolonged by grazing, since long term studies have shown a substantial increase in forage crude protein and digestibility as a result of moderate grazing (Milchunas et al. 1995). Along with improvements in forage quality, fire also increases above-ground plant production, in particular on tallgrass sites burned with intermediate frequency (4-10 year interval) (Seastedt et al. 1991, Ojima et al. 1994). Fryxell (1991) integrated the spatial components 
of forage quality and productivity with the grazing behavior of large herbivores by hypothesizing a direct link between herbivore aggregation and a substantial spatial variability in forage quality or production. Our experiments replicated the model assumptions of Fryxell (1991) by creating a complex spatial and temporal mosaic of unburned and burned patches within a large landscape. Results at both sites support Fryxell's (1991) predictions by showing a consistent spatial aggregation of bison in recently burned areas.

The temporal differences that we observed between the Niobrara Valley Preserve and the Tallgrass Prairie Preserve in the selection of burned areas highlight the significance of the forage production - bison stocking rate - season of burn interaction on landscape heterogeneity. Although the stocking rate on the Tallgrass Prairie Preserve is 0.2 AUM higher than on the Niobrara Valley Preserve (1.2 vs. 1.0 AUM ha ${ }^{-1}$ year $^{-1}$ ), forage production is on average 2 times higher $\left(4,420 \mathrm{~kg} \mathrm{ha}^{-1}\right.$ vs. 2,200 kg ha-1). Also, the average fire-return interval on Tallgrass Prairie Preserve is 5 years, while on the Niobrara Valley Preserve it is 7.5 years. This results in a $7 \%$ larger acreage, with twice the post-fire regrowth, available to bison on the Tallgrass Prairie Preserve. At the bison stocking rate used on the Tallgrass Prairie Preserve, forage regrowth following fire is more slowly and less completely removed by grazing and it matures more rapidly. This leads to a steeper decline in forage quality on newly burned areas of the Tallgrass Prairie Preserve when compared to the Niobrara Valley Preserve (Tieszen et al. 1998).

The attraction of bison to recently burned sites during the dormant season on the Tallgrass Prairie Preserve, but not on the Niobrara Valley Preserve, is likely explained by 2 mechanisms: the fall and winter regrowth of forage at the more southern latitude and the significant physiognomic changes that fire can cause in tallgrass prairies. Although warm season $\left[\mathrm{C}_{4}\right]$ grasses dominate both sites, temperatures following late summer and fall burns are more conducive to forage regrowth on the Tallgrass Prairie Preserve. A significant portion of this regrowth consists of cool season $\left[\mathrm{C}_{3}\right]$ grasses and sedges (Coppedge 1996, Coppedge et al. 1998). Late summer burns on the Niobrara Valley
Preserve do not regrow sufficiently to attract bison during the winter (Pfeiffer and Steuter 1994). On the Niobrara Valley Preserve spring burns have been grazed more intensively during the previous summer, or have a mature forage quality more similar to unburned areas.

Collins $(1987,1992)$ showed a substantial decline in plant community spatial heterogeneity coupled with an increase in the grass component with fire in tallgrass prairies. This physiognomic change should attract bison, since they prefer to graze large, un-fragmented, and relatively uniform plant communities that are dominated by grasses (Vinton and Harnett 1992, Plumb and Dodd 1993, Vinton et al. 1993, Steuter et al. 1995). The subsequent bison grazing forms a unique landscape patch in which rhizomatus grasses are favored over bunchgrasses (Pfeiffer and Steuter 1994, Pfeifer and Hartnett 1995), and forb composition and density changes as a function of season of burn.

Pre-fire results from the Niobrara Valley Preserve suggested that range site would have a significant effect on bison selection of burned areas (Steuter et al. 1995). It now appears that in both the tallgrass and mixed-grass prairies, fire can override range site effects. This allows for a more even, or more clumped, distribution of bison use across the landscape depending on the specifics of the fire regime.

Our results suggest that the details of the fire regime, and bison distribution and abundance within the tallgrass and mixed prairie have a substantial effect on the spatial and temporal distribution of habitat patches. These details were largely controlled by a sequence of Plains Indian cultures during the Holocene (Hanson 1984, Higgins 1986). For example, although Shaw and Lee (1997) report little bison use of the southern Tallgrass prairie from 1806 to 1857, summer burning by earlier Tallgrass prairie inhabitants may have greatly increased winter bison use of this prairie type. Our results re-enforce the notion that human management of the fire regime and large grazers was a basic, but not necessarily static, component of Great Plains grasslands.

\section{Management Implications}

Our research provides detail on how fire determines the distribution of graz- ing by bison within tallgrass prairie and mixed prairie, in the Great Plains. The powerful attraction of bison to burned patches within large heterogeneous landscapes may be used to achieve several management objectives. Since the bison-fire management regime results in between-year rotations of grazing and rest, rather than within-season rotations of grazing deferment, there are larger, longer and possibly more useful contrasts in standing crop on different parts of the landscape for other wildlife species to use. For example, species preferring high residual cover for nesting [waterfowl and Henslow's Sparrow (Ammodramus henslowii)] would be undisturbed in areas unburned and avoided by bison for several years. Species preferring short stature grassland for nesting, feeding, or lekking [Upland Sandpiper (Bartramia longicuada), Chestnut-collared Longspur (Calcarius ornatus), Greater Prairie Chicken (Tympanuchus cupido)] would be able to select recently burned and intensively grazed areas. In addition, forb-rich "food plots" are created by intensive bison grazing and wallowing of late summer burn patches, which experience a short-term increase in low succession plants such as Ambrosia spp. In general, the almost exclusive grazing of graminoids that has been documented for bison should lead to an increase in forb diversity and abundance.

The new growth from prescribed burns could be used to draw bison away from grazing sensitive resources, or attract them to accessible viewing, round up, or harvest areas [an ages-old idea]. Areas burned to control woody plants, and selected by bison during the spring shed of their winter coats, would have additional small tree kill due to rubbing and horning.

Furthermore, the early growth of these burned areas should improve bison quality for lactation and subsequent conception rates following winter nutrient stress. Fall and winter forage quality could be improved by late summer burns in the southern tallgrass prairie, thus improving bison winter condition without supplemental feeding. With the proper stocking rate and fire regime, planned grazing might be distributed with much lower investment in crossfencing. Less cross-fencing may result in a more dynamic spatial and temporal expression of plant communities. 


\section{Literature Cited}

Andrews, P.L. 1986. Behave: fire behavior prediction and fuel modeling system/burn subsystem, Part I. USDA-FS GTR INT 194.

Bailey, D.W., J.E. Gross, E.A. Laca, L.R. Rittenhouse, M.B. Coughenour, D.M. Swift, and P.L. Sims 1996. Mechanisms that result in large herbivore grazing distribution patterns. J. Range Manage. 49:386-400.

Biondini, M.E., B.D. Patton, and P.E. Nyren. 1998. Grazing intensity and ecosystem processes in a northern mixed-grass prairie USA. Ecol. Appl. 8:469-479.

Briske, D.D. and V.J. Anderson. 1990. Tiller dispersion in populations of the bunchgrass Schizachyrium scoparium: implications for herbivory tolerance. Oikos 59:50-56.

Britton, C.M. and A.A. Steuter. 1983. Production and nutritional attributes of tobosagrass following burning. Southwest Naturalist 28:33-41.

Burger, R.E. and R.C. Rothermel. 1984 Behave: fire behavior prediction and fuel modeling system/fuel subsystem. USDA-FS GTR INT-167.

Bourlier, B.G., J.D. Nichols, W.J. Ringwald, P.J. Workman, and S. Clemmons. 1979. Soil survey of Osage county, Oklahoma. USDA-SCS.

Cheney, N.P., J.S. Gould, and W.R. Catchpole. 1993. The influence of fuel, weather and fire shape variables on firespread in grasslands. Int. J. Wildland Fire 3:31-44.

Christopherson, R.J., R.J. Hudson, and R.J. Richmond. 1978. Comparative winter bioenergetics of American bison, yak, Scottish highlander and Hereford calves. Acta Theriologica 23:49-54.

Collins, S.L. 1987. Interaction of disturbances in tallgrass prairie: a field experiment. Ecol. 68:1243-1250

Collins, S.L. 1992. Fire frequency and community heterogeneity in tallgrass prairie vegetation. Ecol. 73:2001-2006.

Coppedge, B.R. 1996. Range ecology of bison on tallgrass prairie in Oklahoma. Ph.D. Diss. Oklahoma State University, Stillwater, Okla. $98 \mathrm{p}$.

Coppedge, B.R., D.M. Leslie, and J.H. Shaw. 1998. Botanical composition of bison diets on tallgrass prairie in Oklahoma. J. Range Manage. 51:379-382.

Coppock, D.L. and J.K. Detling. 1986. Alteration of bison and black-tailed prairie dog grazing interaction by prescribed burning. J. Wildl. Manage. 50:452-455.

Coppock, D.L., J.E. Ellis, J.K. Detling, and M.I. Dyer. 1983. Plant-herbivore interactions in a North American mixed-grass prairie. II. Responses of bison to modifications of vegetation by prairie dogs. Oecologia 56:10-15.

Dyksterhuis, E.J. 1949. Condition and management of range land based on quantitative ecology. J. Range Manage. 2:104-115.

England, R.E. and A. DeVos. 1969. Influence of animals on pristine conditions on the
Canadian grasslands. J. Range Manage. 22:87-94.

Fryxell, J.M. 1991. Forage quality and aggregation by large herbivores. Amer. Nat. 138:478-498.

Hanson, J.R. 1984. Bison ecology in the Northern Plains and a reconstruction of bison patterns for the North Dakota Region. Plains Anthropologist 29:93-113.

Hartnett, D.C., A.A. Steuter, and K.R. Hickman. 1997. Comparative ecology of native and introduced ungulates, p. 72-101. In: F.L. Knopf and F.B. Samson (ed.), Ecology and conservation of Great Plains vertebrates. Ecological Studies Vol. 125. Springer-Verlag, Inc. New York, N.Y.

Heitschmidt, R.K. and C.A. Taylor. 1991. Livestock Production, p. 161-177. In: R.K. Heitschmidt and J.W. Stuth (eds.), Grazing Management: An ecological perspective. Timber Press Inc., Portland, Ore.

Higgins, K.F. 1986. Interpretation and compendium of historical fire accounts in the northern Great Plains. USDI Fish and Wildl. Service Res. Publ. 161.

Hobbs, N.T. 1996. Modification of ecosystems by ungulates. J. Wildl. Manage. 60:695-713.

Jefferies, R.L., D.R. Klein, and G.R. Shaver. 1994. Vertebrate herbivores and northern plant communities: reciprocal influences and responses. Oikos 71:193-206.

Leach, M.K., and T.J. Givnish. 1996. Ecological determinants of species loss in remnant prairies. Science 273:1555-1558.

Malin, J.C. 1953. Soil, animal, and plant relations of the grasslands, historically reconsidered. Sci. Monthly 76:207-220.

Manly, B.F. 1993. Resource selection by animals: statistical design and analysis for field studies. Chapman \& Hall, New York.

McHugh, T. 1972. The time of the buffalo. University of Nebraska Press. Lincoln, Nebr.

McNaughton, S.J. 1984. Grazing lawns: animals in herds, plant form, and coevolution. Amer. Nat. 124:863-886.

Milchunas, D.G., A.S. Varnamkhasti, and W.K. Lauenroth. 1995. Forage quality in relationship to long-term grazing history, current-year defoliation, and water resources. Oecologia 101:366-374.

Mosteller, F. and R.E.K. Rourke. 1973. Sturdy statistics: non parametric and order statistics. Addison-Wesley Publishing Company, Reading, Mass.

Ohr, K.M. and T.B. Bragg. 1985. Effect of fire on nutrient and energy concentration of five prairie grass species. Prairie Naturalist 17:113-126.

Ojima, D.S., D.S. Schimel, W.J. Parton, and C.E. Owensby. 1994. Long- and short-term effects of fire on nitrogen cycling in tallgrass prairie. Biogeochemistry 26:67-84.

Peters, H.F. and S.B. Slen. 1964. Hair coat characteristics of bison, domestic $\mathrm{x}$ bison hybrids, cattalo, and certain domestic breeds of cattle. Canadian J. Anim. Sci. 44:48-57.

Pfeiffer, K.E. and D.C. Hartnett. 1995. Bison selectivity and grazing response of little bluestem in tallgrass prairie. J. Range Manage. 48:26-31.
Pfeiffer, K.E. and A.A. Steuter. 1994. Preliminary response of Sandhills Prairie to fire and bison grazing. J. Range Manage. 47:395-397.

Plumb, G.E. and J.L. Dodd. 1993. Foraging ecology of bison and cattle on a mixed prairie: Implications for natural area management. Ecol. Appl. 3:631-643.

Samson, F.B. and F.L. Knopf (eds.). 1996. Prairie conservation: preserving North America's most endangered ecosystem. Island Press, Covela, Calif.

Seastedt, T.R., J.M. Briggs, and D.J. Gibson. 1991. Control of nitrogen limitation in tallgrass prairie. Oecologia 87:72-79.

Shaw, J.H. and T.S. Carter. 1990. Bison movements in relation to fire and seasonality. Wildl. Soc. Bull. 18:426-430.

Shaw, J.H. and M. Lee. 1997. Relative abundance of bison, elk, and pronghorn on the southern Plains, 1806-1857. Plains Anthropologist 42:163-172.

Shiflet, T.N. 1994. Rangeland cover types of the United States. Soc. Range Mange. Denver, Colo.

Steuter, A.A., C.E. Grygiel, and M.E. Biondini. 1990. A synthesis approach to research and management planning: the conceptual development and implementation. Natural Areas J. 10:61-68.

Steuter, A.A., E.M. Steinauer, G.L. Hill, P.A. Bowers, and L.L. Tieszen. 1995. Distribution and diet of bison and pocket gophers in a sandhills prairie. Ecol. Appl. 5:756-766.

Tieszen, L.L., L. Stretch, and J. Vander Kooi. 1998. Stable isotopic determination of seasonal dietary patterns in bison at four preserves across the Great Plains, p. 130-140. In: L.R. Irby and J.E. Knight (ed.). International Symposium on Bison Ecology and Management in North America. Montana State University, Bozeman, Mont.

Towne, G., T.G. Nagaraja, R.C. Cochran, D.L. Harmon, C.E. Owensby, and D.W. Kaufman. 1988. Comparison of ruminal fermentation characteristics and microbial population in bison and cattle. Appl. Env. Microb. 10:2510-2514.

Vinton, M.A. and D.C. Hartnett. 1992. Effects of bison grazing on Andropogon gerardii and Panicum virgatum in burned and unburned tallgrass prairie. Oecologia 90:374-382.

Vinton, M.A., D.C. Hartnett, E.J. Finck, and J.M. Briggs. 1993. Interactive effects of fire, bison (Bison bison) grazing, and plant community composition in tallgrass prairie. Amer. Midland Nat. 129:10-18.

Voightlander, A.L., R.R. Hammer, R.R. Zink, M.K. Babcock, C. Evens, M.D. Patterson, and H. Schultz. 1992. Soil suvey of Brown county, Nebraska. USDA-SCS.

Weaver, J.E. and F.E. Clements. 1938. Plant ecology [2nd edition]. McGraw-Hill Book Company, Inc., NY USA.

Wright, H.A. and A.W. Bailey. 1982. Fire Ecology: United States and Canada. John Wiley and Sons, New York. 